\title{
PENGARUH JENIS RAGI, MASSA RAGI DAN WAKTU FERMENTASI PADA PEMBUATAN BIOETANOL DARI LIMBAH BIJI DURIAN
}

\author{
Masitho Mega Maharani ${ }^{* 1)}$, Muhammad Bakrie ${ }^{1)}$, Nurlela ${ }^{1)}$ \\ ${ }^{1)}$ Program Studi Teknik Kimia, Fakultas Teknik, Universitas PGRI Palembang \\ *)email : masithomegamaharani20@gmail.com
}

\begin{abstract}
Abstrak
Durian merupakan buah-buahan yang banyak dihasilkan di Sumatera Selatan. Sampai saat ini durian dikonsumsi hanya sebatas bagian salut atau daging, sedangkan biji durian dibuang sebagai limbah. Biji durian mengandung sari pati yang cukup tinggi sebesar 80\% (amilopektin) dan $20 \%$ (amilosa) sehingga dapat difermentasi untuk menjadi bioethanol. Penelitian ini bertujuan untuk mengetahui pengaruh variabel jenis dan massa ragi, serta waktu fermentasi terhadap bioetanol yang dihasilkan. Penelitian ini menggunakan metode eksperimen di Laboratorium Teknik Kimia Universitas PGRI Palembang, bioetanol yang dihasilkan didestilasi lalu dianalisis kadar bioetanol menggunakan alkoholnometer. Hasil penelitian menunjukkan bahwa jumlah bioetanol yang dihasilkan pada kondisi operasi fermentasi menggunakan jenis ragi tape (Saccharomyces Cereviciae), massa ragi 15 gr sebesar 26,762 \% (berat) dan waktu fermentasi 48 jam diperoleh bioetanol sebesar 31,867 \% (berat). Dimasa yang akan datang biji durian dapat menjadi salah satu bahan baku alternatif untuk pembuatan bioetanol.
\end{abstract}

Kata Kunci : Biji Durian, Ragi, Fermentasi, Bioetanol

\section{PENDAHULUAN}

Sumatera Selatan merupakan salah satu provinsi di Indonesia yang memiliki sumber daya alam yang melimpah seperti buah durian. Durian memiliki rasa dan bau yang khas dan hanya dapat dikonsumsi bagian salut atau daging buahnya saja, sedangkan untuk kulit dan biji durian umumnya dibuang karena dianggap tidak bermanfaat dan menjadi limbah. Didalam biji durian terkandung sari pati yang tinggi sebesar $80 \%$ (amilopektin) dan $20 \%$ (amilosa). Karena bijinya mengandung sari pati yang tinggi sehingga mampu untuk dikembangkan dan dimanfaatkan sebagai bahan baku bioetanol.

Berdasarkan potensi tersebut peneliti berharap pemanfaatan limbah biji durian sebagai upaya untuk mengurangi jumlah limbah, juga dapat menambah nilai ekonomis dari biji durian dan diharapkan mampu berperan sebagai salah satu alternatif pembuatan bahan bakar fosil.

Bioetanol merupakan etanol yang berasal dari tumbuh -tumbuhan (biomassa) seperti tebu, biji bijian, umbi - umbian, jagung, dan lain - lain. Ethanol mengalami perubahan jika pati dan amilum direaksikan membentuk gula sederhana (glukosa dan fruktosa) proses hidrolisis, setelah itu etanol mengalami proses fermentasi alkohol yang mengubah glukosa menjadi etanol dengan menambahkan mikroorganisme yeast atau ragi (Khamdiyah, 2010). Reaksi hidrolisis adalah reaksi yang berlangsung sangat lambat karena itu untuk mempercepat laju hidrolisis dengan menambahkan katalis. Katalis yang digunakan dalam mempercepat reaksi hidrolisis pati adalah katalis asam, seperti asam mineral (Nyoman, dkk., 2011). Fermentasi merupakan reaksi biokatalis yang digunakan untuk mengonversi bahan baku yang berupa substrat dengan bantuan enzim dari mikroba menjadi suatu produk baru. Mikroba yang 
biasa digunakan dalam proses fermentasi pembentukan etanol adalah Saccharomyces cerevisae dan lain - lain, dan mikroba tersebut dalam perkembangbiakannya tidak membutuhkan sinar matahari atau anaerob. Etanol hasil fermentasi diperoleh etanol berkadar rendah untuk mendapat etanol 95\% dilakukan distilasi.

\section{Durian}

Durio Zibethinus Murr merupakan nama latin dari salah satu tanaman yang tumbuh dan berkembang di hutan tropis wilayah Asia Tenggara. Durian banyak ditemukan dan sangat populer dikalangan buah -buahan dengan sebutan The King Of The Fruit "Raja dari segala buah". Dalam sejarah Indonesia buah durian sudah ada sejak 1300 tahun lalu, dengan bukti yang terdapat pada permukaan dinding relief Candi Borobudur sebagai buah sesembahan. Pertama kali durian tumbuh di hutan tropis Pulau Sumatera dan Pulau Kalimantan.

Buah durian mempunyai struktur daging yang tebal dan tipis, berwarna putih kekuningan atau temabaga tergantung pada jenisnya serta memiliki biji berwarna coklat muda. Kulit durian memiliki warna hijau hingga kuning kecoklatan, memiliki duri -duri yang tajam. Pohon durian bisa tumbuh sampai berumur tua dan memiliki duri pada permukaan batang.

\section{Biji Durian}

Biji Durian dengan nama latin Durio Zibethinus merupakan bagian buah durian yang berkeping dua, daging berwarna putih kekeruhan, kulit luar berwarna putih kekuningan atau kecoklatan, dan berlendir apa bila di rebus. Biji durian yang mentah tidak bisa dikonsumsi karena mengandung asam lemak siklopropena yang beracun. Persentase konsumsi bagian buah durian salut atau dagingnya 20$35 \%$, kulit $60-75 \%$ dan untuk biji 5-15\%. Umumnya kulit dan dan biji durian tidak termanfaatkan dengan baik dan menjadi limbah menurut masyarakat. Hanya sebagian kecil yang tau bahwa kulit dan biji durian dimanfaatkan sebagai pakan ternak, bahkan dibuang begitu saja dengan cuma-cuma.

Di lingkungan masyarakat biji durian dikonsumsi dengan cara dibakar, direbus, atau juga dikukus. Dalam tiap 100 gr salut biji terdapat 2.5 gr protein, $67 \mathrm{gr}$ air, $2.5 \mathrm{gr}$ lemak, 28.3 gr karbohidrat, 1.4 gr serat, dan mempunyai nilai energi sebesar $520 \mathrm{~kJ}$. Serta mengandung vitamin C, vitamin B1, dan vitamin B2, kalsium, kalium, dan fosfor (Wikipedia, 2020). Kadar karbohidrat biji durian sangat tinggi dibandingkan ubi kayu 34.75 dan ubi rambat 27.9\%. Karbohidrat yang sangat tinggi ini memungkinkan jika dapat diolah lebih lanjut untuk dijadikan sebagai bahan baku subsitusi pengganti sumber karbohidrat atau tepung tapioka.

Jika limbah biji durian termanfaatkan dan diolah dengan serius dapat meminimalisir efek pencemaran lingkungan akibat pembuangan limbah biji durian tersebut juga dapat meningkatkan nilai ekonomis biji durian. Bahkan semakin berkembangnya teknologi pada era sekarang ini biji durian dimanfaatkan sebagai alternatif pengganti bahan bakar fosil dengan cara pembuatan bioetanol. Sebelum biji durian diolah menjadi tepung harus dilakukan pencucian, perebusan, pengupasan, pengirisan, perendaman, pengeringan, dan penggilingan.

\section{Bioetanol}

Bioetanol adalah ethanol yang diperoleh dari sumber daya alam yang bisa diperbarui sebagai salah satu alternatif bahan bakar nonfosil dan secara umum dapat digunakan dengan cara proses fermentasi. Ethanol dengan nama senyawa ethyl alkohol dengan rumus molekul $\left(\mathrm{C}_{2} \mathrm{H}_{5} \mathrm{OH}\right)$ mengandung larutan bening yang tidak berwarna, yang dapat terurai secara biologis (biodegradable), memiliki toksisitas yang rendah dan tidak menyebabkan pencemaran polusi udara yang besar jika mengalami kebocoran.

Proses pembuatan bioetanol dari limbah biji durian berlangsung melalui dua tahap, yaitu pertama melalui proses hidrolisis pati biji durian membentuk glukosa dan selanjutnya dengan proses fermentasi glukosa menjadi etanol dengan menambahkan ragi Saccharomyces cerevisiae untuk mempercepat reaksi fermentasi. Proses metamorfosis karbohidrat menjadi gula sederhana disebut hidrolisis. Hidrolisis dapat 
diartikan sebagai reaksi yang terjadi antara suatu zat dengan air $\left(\mathrm{H}_{2} \mathrm{O}\right)$ sehingga senyawa tersebut dapat mengalami penguraian (Ismuyanto, dkk., 2013).

\section{Hidrolisis}

Proses hidrolisis dengan cara enzimatis banyak digunakan karena akan mengurangi dampak lingkungan dibandingkan dengan penambahan dengan menggunakan katalis asam pada proses fermentasi dapat menghasilkan bioetanol (Seftian, dkk., 2012). Proses konversi yang terjadi antara karbohidrat menjadi gula sederhana disebut hidrolisis. Hidrolisis merupakan reaksi yang terjadi antara suatu zat dengan air $\left(\mathrm{H}_{2} \mathrm{O}\right)$ sehingga senyawa tersebut akan terurai. Proses reaksi hidrolisis berlangsung lama sehingga perlu menambahkan suatu katalis untuk mempercepat terjadinya suatu reaksi berupa katalis asam klorida $(\mathrm{HCl})$ atau asam sulfat $\left(\mathrm{H}_{2} \mathrm{SO}_{4}\right)$.

\section{Fermentasi}

Kata fermentasi dengan Bahasa Latin "fervere" yang artinya merebus. Fermentasi merupakan reaksi biokatalis yang biasa digunakan untuk mengonversi bahan baku substrat oleh enzim dengan bantuan mikroba menghasilkan produk yang diinginkan. Mikroba terdiri dari bakteri, jamur (mold) dan khamir (yeast). Proses fermentasi yang terjadi mengubah glukosa menjadi etanol (alkohol) dengan menambahkan Saccharomyces cerevisiae yaitu ragi tape dan ragi instan. Alkohol yang dihasilkan dari proses fermentasi yaitu alkohol yang mengandung kadar 8-10\% volume.

Etanol yang diperoleh dari proses fermentasi perlu ditingkatkan lagi kualitasnya dengan memfilter kembali dari zat-zat yang tidak dibutuhkan. Alkohol yang diperoleh dari proses fermentasi masih mengandung gas-gas yang dihasilkan dari perubahan glukosa menjadi etanol atau bioetanol dan membuang aldehid yang ada. Gas yang dihasilkan pada saat mengalami proses fermentasi umumnya $35 \%$ volume, maka untuk mendapatkan etanol atau bioetanol yang berkualitas sempurna, etanol atau bioetanol harus dihilangkan dari gas tersebut. Kadar etanol yang diperoleh dari proses fermentasi yang mencapai $8-10 \%$ belum maksimal, sehingga untuk memperoleh etanol yang memiliki kadar alkohol 95\% dibutuhkan proses lainnya, yaitu proses destilasi.

\section{Ragi}

Ragi adalah zat yang dapat menyebabkan terjadinya proses fermentasi. Ragi umumnya terdiri dari beberapa jenis salah satunya Saccharomyces cereviseae. Saccharomyces cereviseae merupakan jenis khamir yang banyak digunakan untuk memproduksi minuman beralkohol seperti anggur, bir, dan juga banyak digunakan dalam fermentasi adonan dalam pembuatan roti dan fermentasi dalam pembuatan tape. Khamir yang dipilih haruslah tumbuh dengan baik yang mempunyai toleransi yang tinggi terhadap alkohol, dan mampu menghasilkan alkohol dengan jumlah yang banyak. Ragi Saccharomyces cerevisiae digunakan untuk meningkatkan hasil yang diperoleh dari produksi bioethanol dari gula karena dalam proses tersebut tidak membutuhkan sinar matahari dalam proses pertumbuhannya dan dapat langsung digunakan untuk fermentasi bioetanol karena tidak diperlukan persiapan inokulum secara khusus.

\section{Ragi Tape}

Ragi tape merupakan ragi yang banyak digunakan sebagai bahan dalam pembuatan tape. Proses fermentasi pada tape berasal dari karbohidrat seperti umbi-umbian, beras ketan, beras putih, dan lainnya yang terfermentasi dengan ragi menghasilkan cairan tape yang mengandung alkohol, berwarna putih dan jika dilihat akan tampak berlendir, serta memiliki rasa keasaman yang manis. Ragi tape sangat banyak digunakan dalam fermentasi untuk memperoleh bioethanol, dan biasanya berbentuk seperti bulat pipih, berwarna putih dengan tekstur halus

\section{Ragi Roti Instan}

Ragi roti instan adalah ragi instan yang digunakan sebagai bahan pengembang untuk fermentasi 
pembuatan adonan kue, roti, donat, dan lain - lain. Ragi dapat dibedakan dari tekstur bentuk dan kadar kelembapannya. Jika semakin tinggi kadar kelembapannya, maka semakin pendek masa tahan pertumbuhannya. Ragi roti instan merupakan ragi kering yang banyak dijual dipasaran dan sangat mudah didapat, sehingga menjadi salah satu alternatif pengganti untuk fermentasi bioetanol yang memiliki ketahanan yang lama dengan struktur butiran kecil yang kasar.

\section{METODELOGI PENELITIAN}

Penelitian ini dilakukan dengan menggunakan metode eksperimen di Laboratorium Teknik Kimia Universitas PGRI Palembang. Proses produksi bioetanol dilakukan dengan dua tahap yaitu yang pertama dilakukan hidrolisis dan dilanjutan dengan proses fermentasi. Selanjutnya untuk menghasilkan kadar etanol 95\%, harus dilakukan proses destilasi dengan variabel teliti : jenis ragi, massa ragi. dan waktu fermentasi.

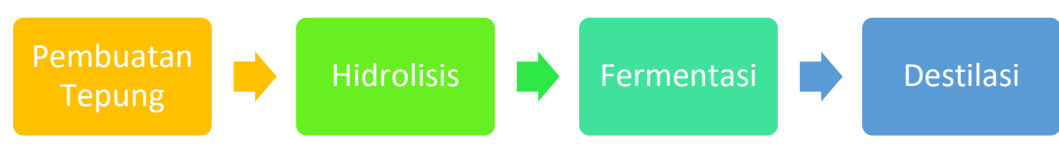

\section{Gambar 1. Diagram Proses Pembuatan Bioetanol}

Metode analisa yang dilakukan dalam penelitian ini dengan cara menggunakan alkohol meter. Prinsip kerja alat ukur alkohol meter yaitu berdasarkan berat jenis campuran antara alkohol dan air. Dibagian atas alkohol meter dilengkapi dengan skala ukur yang menunjukkan garis kadar alkohol.

\section{Cara Kerja}

\section{Pembuatan Tepung Biji Durian}

Tahap pertama pada penelitian ini yaitu siapkan biji durian sebanyak $20 \mathrm{~kg}$. Biji durian tersebut direndam dan dicuci sampai benar-benar bersih dari sisa-sisa daging buah yang masih menempel agar nantinya tidak akan mempengaruhi kualitas tepung yang akan dibuat. Kemudian biji durian direbus didalam air mendidih untuk mempermudah agar kulit arinya bisa dikupas serta menghilangkan lendir biji durian. Selanjutnya kupas kulit ari biji durian dan iris inti daging biji duriannya. Setelah itu, dicuci kembali untuk menghilangkan lendir kedua kali. Kemudian tahap pengeringan, inti daging yang telah diiris tiriskan pada tampa dengan tersusun rapi dengan jarak tidak telalu dekat karena untuk mempercepat proses pengeringan. Selanjutnya jemur inti daging biji durian di bawah terik sinar matahari agar kering selama 3-5 hari atau dengan menggunakan pengeringan melalui oven sekitar \pm 45 menit sampai kadar air pada inti daging biji durian cukup kering. Tahap terakhir haluskan inti daging biji durian tersebut yang telah dikeringkan menggunakan blender sampai menjadi halus dan menjadi powder atau tepung. Selanjutnya proses pembuatan tepung biji durian selesai kemudian dilanjutkan pada tahap hidrolisis.

\section{Proses Hidrolisis}

Setelah memperoleh tepung biji durian dilanjutkan dengan proses hidrolisis untuk mempercepat terjadinya pembentukan glukosa pada proses fermentasi. Siapkan 100 gr tepung biji durian yang dimasukkan ke dalam panci pemanasan dengan menambahkan $30 \mathrm{ml}$ larutan HCL dengan konsentrasi 3 M. Selanjutnya dipanaskan dengan pada suhu $50-70^{\circ} \mathrm{C}$. Hasil hidrolisis tersebut disaring dan dipisahkan antara cake dengan larutan hidrolisat serta diukur berapa volumenya. 


\section{Proses Fermentasi}

Proses selanjutnya adalah proses fermentasi untuk memperoleh bioetanol. Yang pertama menyiapkan terlebih dahulu lima belas \pm 15 toples untuk masing - masing wadah fermentasi. Kemudian juga siapkan ragi tape dan ragi roti instan yaitu masing - masing sebanyak 5 gr, $10 \mathrm{gr}, 15 \mathrm{gr}, 20 \mathrm{gr}$, dan 25 gr. Selanjutnya larutan hidrolisat dimasukkan kedalam toples dengan menambahkan masing - masing ragi yang disesuaikan pada tabel rencana percobaan. Pertama memvariasikan jenis ragi, setelah itu memvariasikan massa ragi dengan 5 perlakuan yaitu 5 gr, 10 gr, 15 gr, 20 gr, dan 25 gr dan memvariasikan lama waktu fermentasi dengan 5 perlakuan waktu yaitu 24 jam, 36 jam, 48 jam, 60 jam dan 72 jam. Tahap tersebut disesuaikan dan dilakukan berulang berdasarkan pada tabel rencana percobaan dengan variasi yang diajalankan. Setelah proses fermentasi selesai, dilakukan pencatatan hasil akhir volume untuk dilanjutkan pada proses destilasi.

\section{HASIL DAN PEMBAHASAN}

Tabel 1. Hasil Fermentasi Dengan Variasi Jenis Ragi Tape dan Ragi Roti Instan

\begin{tabular}{|c|c|c|c|c|c|c|c|}
\hline \multirow{2}{*}{ Jenis Ragi } & \multicolumn{3}{|c|}{ Sampel Hidrosilat $(\mathrm{ml})$} & \multicolumn{3}{c|}{ Hasil Fermentasi $(\mathrm{ml})$} & Hasil Bioetanol \\
\cline { 2 - 8 } & 1 & 2 & 3 & 1 & 2 & 3 & Berat Kadar $(\%)$ \\
\hline Ragi Tape & 432 & 424 & 490 & 345 & 336 & 372 & 16,829 \\
\hline Ragi Roti Instan & 419 & 440 & 482 & 355 & 364 & 372 & 11,534 \\
\hline
\end{tabular}

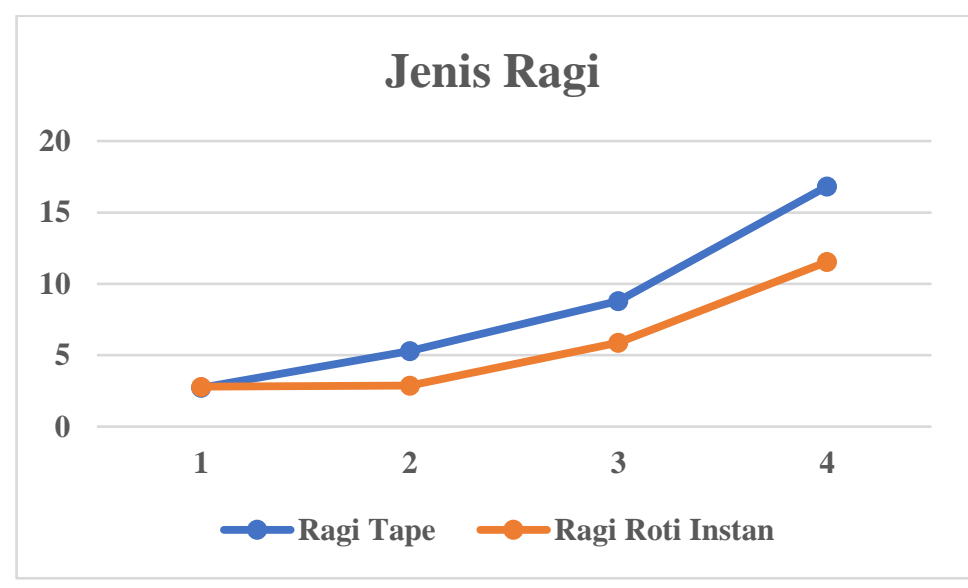

Gambar 2. Pengaruh Variasi Jenis Ragi Terhadap Kadar \% Berat

Dari gambar grafik diatas dapat disimpulkan bahwa fermentasi jenis ragi dengan waktu 48 jam menggunakan ragi tape dan ragi roti instan dengan berat bahan baku tepung $100 \mathrm{gr}$, dan massa ragi 10 gr, menghasilkan kadar bioetanol paling banyak menggunakan ragi tape yaitu sebesar 16,829\% sedangkan menggunakan ragi roti instan menghasilkan bioetanol sebesar 11,534\%. 
Tabel 2. Hasil Fermentasi Dengan Variasi Massa Ragi

\begin{tabular}{|c|c|c|c|c|c|c|c|}
\hline \multirow{2}{*}{$\begin{array}{c}\text { Massa } \\
\text { Ragi }\end{array}$} & \multicolumn{3}{|c|}{ Sampel Hidrosilat (ml) } & \multicolumn{3}{|c|}{ Hasil Fermentasi (ml) } & \multirow{2}{*}{$\begin{array}{c}\text { Hasil Bioetanol } \\
\text { Berat Kadar (\%) }\end{array}$} \\
\hline & 1 & 2 & 3 & 1 & 2 & 3 & \\
\hline 5 & 425 & 459 & 442 & 320 & 341 & 330 & 10,422 \\
\hline 10 & 432 & 490 & 424 & 345 & 372 & 336 & 16,829 \\
\hline 15 & 484 & 467 & 495 & 368 & 340 & 386 & 26,762 \\
\hline 20 & 458 & 431 & 462 & 374 & 315 & 359 & 18,675 \\
\hline 25 & 450 & 432 & 463 & 350 & 324 & 310 & 7,874 \\
\hline
\end{tabular}

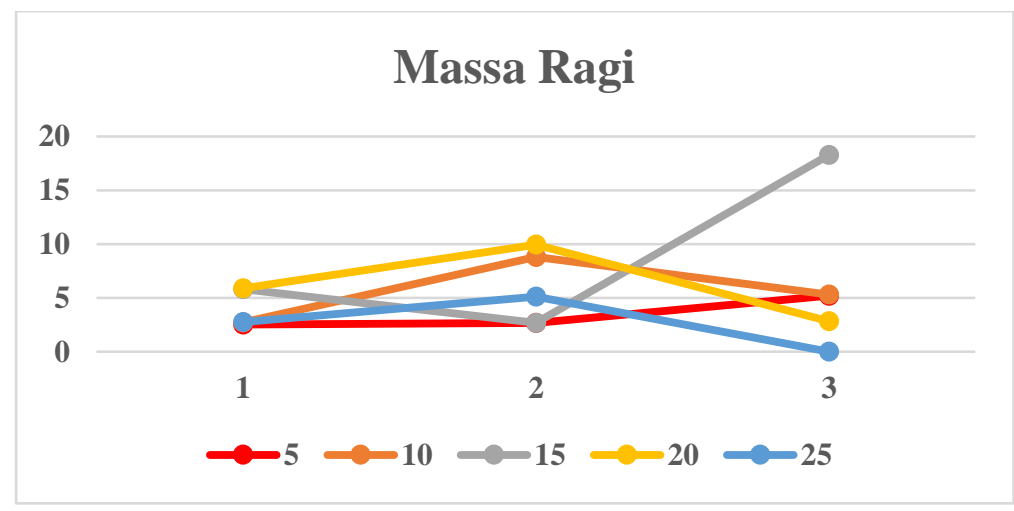

Gambar 3. Pengaruh Variasi Massa Ragi Terhadap Kadar \% Berat

Hasil penelitian pada gambar grafik di atas menunjukkan bahwa dengan menggunakan ragi tape (Saccharomyces Cereviae), berat bahan baku tepung 100 gram, dan waktu fermentasi 48 jam tetap menghasilkan bioetanol dengan kadar paling optimal pada massa ragi 15 gram yaitu 26,762\% sedangkan massa ragi 5 gram menghasilkan kadar bioetanol paling sedikit sebesar 10,422 \%, pada massa ragi 10 gram menghasilkan kadar bioethanol sebesar $16,829 \%$, pada massa ragi 20 gram menghasilkan kadar bioetanol yaitu sebesar 18,675 \% dan pada massa ragi 25 gram menghasilkan kadar bioetanol yaitu sebesar 7,874 \%. Hal ini dapat disimpulkan bahwa pada massa ragi 15 gr mikroba atau yeast terjadi masa pertumbuhan menjadi etanol paling optimal.

Tabel 3. Hasil Fermentasi Dengan Variasi Waktu Fermentasi

\begin{tabular}{|c|c|c|c|c|c|c|c|}
\hline \multirow{2}{*}{$\begin{array}{c}\text { Waktu } \\
\text { Fermentasi }\end{array}$} & \multicolumn{3}{|c|}{ Sampel Hidrosilat (ml) } & \multicolumn{3}{c|}{ Hasil Fermentasi (ml) } & Hasil Bioetanol \\
\cline { 2 - 7 } & $\mathbf{1}$ & $\mathbf{2}$ & $\mathbf{3}$ & $\mathbf{1}$ & $\mathbf{2}$ & $\mathbf{3}$ & Berat Kadar (\%) \\
\hline $\mathbf{2 4}$ & 436 & 417 & 446 & 325 & 310 & 348 & 8,059 \\
\hline $\mathbf{3 6}$ & 458 & 427 & 462 & 353 & 330 & 322 & 10,714 \\
\hline $\mathbf{4 8}$ & 476 & 442 & 480 & 388 & 345 & 363 & 31,867 \\
\hline $\mathbf{6 0}$ & 484 & 467 & 495 & 368 & 340 & 386 & 26,762 \\
\hline $\mathbf{7 2}$ & 423 & 410 & 449 & 346 & 329 & 371 & 16,703 \\
\hline
\end{tabular}




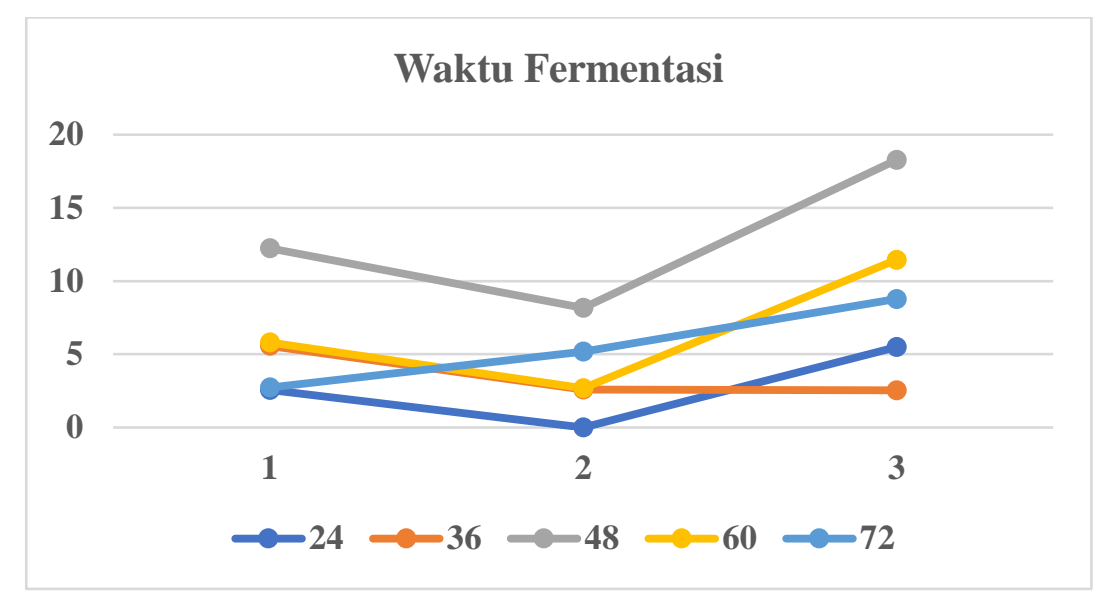

\section{Gambar 4. Pengaruh Variasi Waktu Fermentasi Terhadap Kadar \% Berat}

Hasil penelitian pada grafik di atas dapat disimpulkan bahwa variasi waktu fermentasi dengan menggunakan ragi tape (Saccharomyces Cereviae), berat bahan baku tepung 100 gram, dan massa ragi 15 gram menghasilkan kadar etanol paling baik dengan waktu 48 jam sebesar 31,867\%. Pada waktu fermentasi 24 jam menghasilkan kadar bioetanol paling sedikit sebesar 8,059\%, pada waktu fermentasi 36 jam menghasilkan kadar bioetanol sebesar 10,714 \%, pada waktu 60 jam menghasilkan kadar bioetanol yaitu $26,762 \%$ dan pada waktu fermentasi 72 jam menghasilkan kadar bioetanol yaitu sebesar $16,703 \%$. Hal ini menunjukkan bahwa pada waktu fermentasi 48 jam pembentukan glukosa menjadi etanol paling optimal.

\section{Pengaruh Jenis Ragi Terhadap Kadar Bioetanol (\%) Yang Dihasilkan}

Pada proses terjadinya hidrolisis yang mengubah glukosa dan $\mathrm{CO}_{2}$, kemudian asam asetat diubah membentuk alkohol dengan proses fermentasi. Dalam penelitian ini variasi jenis ragi yang digunakan adalah dan Ragi tape (Saccharomyces Cerevisiae) dan Ragi roti instan memvriasikan massa ragi dan waktu fermentasi dianggap untuk masing - masing jenis ragi yang digunakan.

Ragi roti instan atau Instan Yeast memiliki kelembaban 4\% sehingga bisa langsung dipakai tanpa perlu didehidrasi terlebih dahulu. Sedangkan Ragi tape digunakan untuk meningkatkan hasil produksi bioethanol dari gula karena dalam prosesnya tidak membutuhkan sinar matahari dalam pertumbuhannya (Minarni, dkk, 2013). Kedua ragi tersebut miliki sifat yang stabil, tidak menyebabkan bahaya atau dapat menimbulkan racun dan sangat mudah dicari dipasaran. Hasil penelitian fermentasi bioetanol menggunakan ragi tape lebih tinggi dari ragi roti instan. Karena dalam petumbuhan pertama kali bakteri tumbuh lebih cepat dengan nutrisi pati yang tersedia.

Dari gambaran yang sudah dijelaskan diatas dapat disimpulkan bahwa jenis ragi sangat berpengaruh terhadap kadar bioethanol yang dihasilkan. Pada gambar tersebut dapat dilihat hasil tertinggi pada variasi jenis ragi yang menghasilkan kadar bioethanol tertinggi adalah ragi tape dengan kadar bioethanol sebesar 16,829\%. Dengan demikian fermentasi limbah biji durian menggunakan ragi tape dapat menghasilkan kadar bioetanol yang cukup optimal dalam proses pembuatan bioetanol.

\section{Pengaruh Massa Ragi Terhadap Kadar Bioetanol (\%) Yang Dihasilkan}

Proses fermentasi mengubah glukosa dan $\mathrm{CO}_{2}$, menjadi alkohol diperoleh menggunakan ragi tape (Saccharomyces Cerevisiae). Pada penelitian ini menvariasikan massa ragi yang digunakan adalah $5 \mathrm{gr}$, 10 gr, 15 gr, 20 gr, dan 25 gr variasi jenis ragi sudah didapat dari penelitian sebelumnya sedangkan waktu fermentasi dianggap tetap terlebih dahulu untuk masing - masing massa ragi yang digunakan. 
Pada beberapa penelitian ditunjukkan perbandingan massa ragi dengan berat $5 \mathrm{gr}$ mulai mengalami kenaikan dan 10 gr mengalami penurunan kadar bietanol. Hal terjadi disebabkan karena semakin banyaknya jumlah ragi yang ditambahkan akan mempengaruhi kadar bioethanol yang diperoleh (Dahlan,dkk 2012).

Hal ini dapat disimpulkan pada penelitian yang memvariasikan massa ragi dengan menggunakan ragi tape (Saccharomyces Cerevisiae) dan waktu fermentasi tetap dapat dilihat bahwa massa ragi sangat berpengaruh terhadap hasil kadar bioethanol. Pada gambar tersebut dapat dilihat bahwa massa ragi $5 \mathrm{gr}$ dan 10 gr mulai mengalami kenaikan dan titik optimal menunjukkan pada massa ragi 15 gr dengan kadar bioethanol sebesar $26,762 \%$ sedangkan pada massa ragi 20 gr dan 25 gr kadar bioethanol mengalami kecenderungan penurunan.

\section{Pengaruh Waktu Fermentasi Terhadap Kadar Bioetanol (\%) Yang Dihasilkan}

Pada penelitian ini memvariasikan waktu fermentasi yang digunakan yaitu 24 jam, 36 jam, 48 jam, 60 jam, dan 72 jam dengan penelitian sebelumnya menggunakan ragi tape (Saccharomyces Cerevisiae) dengan massa ragi 15 gram menunjukkan hasil bahwa kadar bioethanol lama fermentasi oleh 48 jam yang paling besar dan lama fermentasi oleh 24 jam paling rendah. Pada lama fermentasi 48 jam kadar bioethanol mencapai optimal disebabkan karena glukosa terurai sempurna menjadi etanol dengan kadar tinggi sebesar 31,867 \%. Pada lama fermentasi 60 jam mengalami penurunan dan kembali cenderung menurun pada lama fermentasi 72 jam karena adanya ragi yang mengalami fase kematian pada saat proses fermentasi berlangsung. Fase kematian khamir atau mikroba pada fermentasi bioetanol ini ditandai dengan terjadinya penurunan produksi etanol (Umam, 2018). Kematian ragi ini bisa disebabkan oleh kurangnya nutrisi yang terdapat pada proses fermentasi sesuai pada penelitian menurut (Jayanti dan Solfarina, 2015).

Adapun nutrisi yang diperlukan ragi untuk dapat tumbuh dan berkembang biak menurut Hidayat et al. (2006) antara lain unsur karbon, nitrogen, pospor, mineral-mineral, serta vitamin. Sel membutuhkan nutrisi yang cukup supaya bisa menggunakan gula yang tersedia sehingga proses fermentasi dapat berjalan dengan baik. Jika nutrisi yang diperlukan tidak tersedia, maka gula akan tersisa pada akhir fermentasi dan dapat menurunkan efisiensi fermentasi.

Pada beberapa penelitian yang telah dilakukan oleh (Dake et al., 2010); (Rubbiyo-Arroyo et al., 2011); Sadik dan Halema (2014) bahwa lama waktu ferementasi bioethanol yang optimum adalah sekitar 24 - 72 jam. Dilihat dari gambar grafik 4.3. diketahui bahwa semakin bertambahnya waktu fermentasi maka kadar bioethanol akan semakin mengalami kenaikan sampai batas waktu tertentu dan kemudian akan mengalami penurunan.

\section{KESIMPULAN}

Dari hasil penelitian ini Jenis ragi yang menghasilkan fermentasi etanol yang optimal menggunakan ragi tape (Saccharomyces Cerevciae) yang diperoleh sebanyak 16,829 \% (berat). Massa ragi yang menghasilkan fermentasi etanol optimal diperoleh massa ragi 15 gr sebanyak 26,762\% (berat).Waktu fermentasi yang dapat menghasilkan etanol optimal dengan waktu fermentasi 48 jam sebanyak $31,867 \%$ (berat).

\section{DAFTAR PUSTAKA}

Dahlan M.Hatta, Jhonprimen H.S, dan Andreas Turnip (2012). Pengaruh Massa Ragi, Jenis Ragi, dan Waktu Fermentasi Pada Bioetanol Dari Biji Durian. Jurnal Teknik Kimia.

Dake, M.S ., Amarapurkar, S.V., Salunkha, M.L., dan Kamble, S.R. 2010. Production of Alcohol by 
Saccharomyces sp. Using Natural Carbohydrate Sources. Advance Biotech Vol. 10 (06): 37-41 Hidayat, N., M. C. Padaga, dan S. Suhartini. 2006. Mikrobiologi Industri. Yogyakarta : Andi.

I Nyoman, W. P., I Gusti B. W., I Nyoman S. W., 2011, Proses Treatment Dengan Menggunakan NaOCl

Dan H2SO4 Untuk Mempercepat Pembuatan Bioetanol Dari Limbah Rumput Laut Eucheuma Cottonii, Jurnal Ilmiah, Hal. 64-68

Ismuyanto, B., Anugrahini, S. F. A., \& Indahyanti, E. (2013). Kinetika reaksi hidrolisis pati biji durian (durio zibethinus murr) menjadi glukosa dengan variasi temperatur dan waktu. Kimia Student Journal, 2(1), 344-350.

Jayanti Titi dan Solfarina. (2015). Pembuatan Bioetanol Dari Biji Durian (Durio Zibethinus). 110-115. Jurnal Teknik Kimia

Khamdiyah, N., 2010, Pembuatan Etanol Dari Alga Merah Jenis Eucheuma spinosum Dengan Sakarifikasi Dan Tanpa Sakarifikasi Pada Variasi Lama Fermentasi, Skripsi, Fakultas Sains Dan Teknologi, Universitas Negeri (UIN) Maulana Malik Ibrahim Malang.

Minarni Neni, Ismuyanto Bambang, Sutrisno (2013). Pembuatan Bioetanol Dengan Bantuan Saccharomyces Cerevisiae Dari Glukosa Hasil Hidrolisis Biji Durian (Durio Zibethinus). 36-42.

Rubio-Arroyo, M.F., Vivanco-Loyo, P., Juarez, M., Poisot, M., dan Ramirez-Galicia, G. 2011. BioEthanol Obtained by Fermentation Process with Continous Feeding of Yeast. J. Mex. Chem. Soc. 2011, 55(4): 242-245

Sadik, M.V. dan Halema, A.A. 2014. Production of Ethanol from Molasses and Whey Permeate using Yeasts and Bacterial Strains. Internasional Journal of Current Microbiology and Applied Sciences. Volume 3 Number 3: 804-818.

Seftian, D., Antonius, F., \& Faizal, M. (2012). Pembuatan ethanol dari kulit pisang menggunakan metode hidrolisis enzimatik dan fermentasi. Jurnal Teknik Kimia, 18(1), 10-18.

Umam Muzid Syauqil (2018). Pengaruh Konsentrasi Ragi Roti (Saccharomyces Cereviae) Dan Waktu Fermentasi Terhadap Kadar Bioethanol Nira Siwalan (Borasus Flabellifer L). Jurnal Mahasiswa Wikipedia.Org, diakses tanggal 20 Juni 2020, pukul 19.15 WIB. 